\title{
Brides across the Border (Syrian Druze Bribes Who Have Married Israeli Druze Men of the Golan Heights after the Israeli Occupation in 1967)
}

\author{
Janan Faraj Falah, Yosef Maman, Wafa Amasha \\ The Arab College for Education, Ohalo College, Katzrin, Israel \\ Email: Jananf81@gmail.com, docmaman1@gmail.com
}

How to cite this paper: Falah, J.F., Maman, Y. and Amasha, W. (2017) Brides across the Border (Syrian Druze Bribes Who Have Married Israeli Druze Men of the Golan Heights after the Israeli Occupation in 1967). Open Journal of Social Sciences, 5, 289-303.

https://doi.org/10.4236/jss.2017.55021

Received: February 20, 2017

Accepted: May 20, 2017

Published: May 23, 2017

Copyright $\odot 2017$ by authors and Scientific Research Publishing Inc. This work is licensed under the Creative Commons Attribution International License (CC BY 4.0).

http://creativecommons.org/licenses/by/4.0/

\begin{abstract}
This article describes the story of six Druze women from various ages, who were born in Syria and had married Druze men from the Golan Height, under the Israeli rule. These marriages had created a separation between the women and their family in Syria, and in some cases the separation was total and the women ceased seeing or meeting their families at all. Israel and Syria do not have diplomatic relations; in fact, they are considered enemies. This article displays the problems the Druze women to face, as well as to cope with the new society on the Israeli side.
\end{abstract}

\section{Keywords}

Golan Highs, Brides, Israel, Syria, New Society

\section{Introduction}

The differences between Druze's conditions and lifestyle across the two sides of the border-the Syrian side and the Israeli one, are tremendous. Among the Druze, as in other Arab communities in the Middle East, at a time of marriage, the bride is moving to the village or city of the bridegroom and his family, and for this special condition, the Israeli authority allows the Druze residents of the Golan Heights to marry their Syrian relatives and to come and live in Israel. Naturally, the Druze women cannot return to Syria, only in case of divorce (in the year 2010 a couple was married in the village of Bokata, but after few months they have decided to get divorced and the Druze bribe had moved to another family until her legal papers were arranged). Due to the women's longing to their parents and to their homeland, and due to the geographical proximity, a 
special situation has been formed, "The Hill of Shouts" (Tal al Saihat), a kind of a fence which begins in Magdel Shams (the largest Druze village in the Golan Heights) and the Syrian village Ein Tina, in which the families from both sides of the border are able to contact their families, talk to each other by loudspeakers or just to look at each other through magnifying glasses. The Druze are not allowed to marry spouses out of their community, which is the reason why they are looking for a Druze spouse inside or outside their village. Many young Druze women from the Golan Heights had married Israeli Druze, as well as many Israeli Druze women, who also had married men from the Golan Heights, yet, in smaller percentages. In addition, due to the blood relationship with the families in Syria, the number of marriages between Druze of these countries was greater than those of the marriage in the Golan Heights and Lebanon.

This article presents a study of Syrian and Lebanon women who had married the Golan Heights men; the emphasis is on the Druze women's former lives at the homeland, their present lives in Israel, and their expectations before the wedding.

\section{The Druze}

The number of Druze community worldwide stands on about one million people (Fararj Falah 2016) [1], mainly in three countries: Lebanon, Syria and Israel. In Syria, their number is about 450,000 people, in Lebanon 350,000 people and in Israel 100,000 people.

In the land of Israel the community residents in the regions of the Galilee, Carmel and The Golan Heights (Faraj Falah 2016) [2].

The Druze also live in South America and in the United States, Canada, Australia, the Philippines, Saudi Arabia, Jordan and more.

The Druze are called "Sons of Maarof (The sons of grace)" or "Almoahadon" (the special ones), meaning- the Monotheistic. The name Druze is derived from the name of Muhammad bin Ismail Nashtakin ad-Darazī, one of its early preachers.

The Druze believe that their religion exists from the beginning of humanity, and always have been Monotheistic, yet had chosen to reveal their religion only on the year 1017, it is called "The Generation of Al-Kashshaaf" (the revelation or exposure) [3] in Egypt at the $11^{\text {th }}$ century, under the reign of Al-Hakim bi-Amr Allah (996-1021).

The period of the spreading of the religious continued until the year 1043. By that time the common people were not allowed to join the religion, in the exception of two families: The Jumblatt family and The Arsalan, the families of an important "Emirs" (rulers) (Faraj Falah 2005) [3].

One of the most prominent group who had joined the Druze movement (when it was allowed) were "The sons of Tanoch", whose origin was in Iraq and later on in Syria and Lebanon. In the 18th century The Druze had begun to move from Lebanon (the Mount Lebanon) to the Horan (Mount Jabal al-Druze) in Syria (Falah-Kasim1991, Dana 1999) [4] [5]. 
The Druze religion is first and foremost secret. The secrecy is its most significant, major element, and it is known only for few and outstanding individuals in the community, who are called 'The Uqqāl' ("The Educated", "The Scholars").

The rest of the community is the "Gohal" ("The Ignorant") who are unfamiliar with the religion. The Druze are called in Arabic "The Mountain People", for they reside in the mountains, isolated from the environment. This is also valid to Syria and Lebanon (Ben-Dor, 1996, p. 53) [6].

The Druze are a minority in the Middle East countries, the entire community is only 1.14 million people. The three major Druze communities are located in Syria, Lebanon and Israel. There are approximately 600,000 Druze in Syria (about $3.5 \%$ of its population), in Lebanon the number of Druze reach to approximately 400,000 people (about $7 \%$ of the population), by the end of the year 2004 , the Druze community in Israel was 113,000 people (about $1.6 \%$ of the population, and $8.4 \%$ of the general minority populations in Israel). According to various estimates, there are approximately 100.000 Druze living in Jordan, Saudi Arabia, and other countries in North America, South America, Australia and the Philippines (Avivi, 2007, p. 5) [7].

As stated, The Druze do not have a country of their own, therefore they have developed throughout history a loyalty to the country of their residence. Their residence in a particular country is as a result of particular circumstances that had forced them to adjust the country and its rule. Some associate this to the "Takia", the self-modesty which embraces the way of the "Marranos" in order to survive, thus, their ability to identify with the country of their residence, despite being a minority. The identification throughout the generations had become almost a duty, in order to fulfill the Commandment of Living (Shtendle, 1992, pp. 118-119) [8].

\subsection{The Druze Woman}

The Druze religion equals women with' men, although, in practice, equality does not exist, for the Druze society is influenced by Arabic patriarchic society.

The Druze religion prohibits polygamy, and demands women's full consent to marriage; however, it strictly prohibits its men to marry women from different community or religion, and vice versa (faraj falah 2016) [2]. A person who violates this law is banned to be eliminated and outcaste out of the community. This custom is a result of the "Eelders" (religious leaders) to create greater cohesion among the community members, and thus, they had come to the conclusion that marriage within the clan/community would develop mutual love and caring, an element which was needed at the past to cope with pressure and persecution of their environment (Amal Nasr A-Din, p. 74) [9].

The second reason lies in the fact that Druze cannot convert their religion, therefore, in a situation that community is closed to conversion, marriage outside the community is not an option. Hence, an endogamy is still popular in the Druze community. Most Druze families rather marry their daughter to her cousin or at least to another relative, or a spouse from the same village (Falah, 2000 
pp. 112-113) [10].

\subsection{The Golan Heights}

The Golan Heights (in Arabic: Haḍbatu 'l-Jawlān) is a southern region in Syria, which was largely occupied by Israel in the war of June 1967. Before the occupation approximately 130,000 Syrian Arabs were living in the province city Quneitra and around it in 140 villages and towns, and in 60 smaller communities who are called "Mazra'a" (farms). Most of the Syrian inhabitants ran away or were expelled during the war or after, and eventually, only 6400 residents were left in five villages, most of the residents were Druze (The Issue of The Golan Heights, October 2003, p.3-4 Daniel Ram, 2010) [11].

Today, there is one Alawee village (Alawiyyahin in Arabic) by the name of Alrajar and four Druze villages by the names: Majdal Shams, Mas'ade, Buqa'ata and Ein-khania.

Since their separation from Syria in 1967, the social and martial relations between the Syrian inhabitants and the Golan Heights inhabitants have been decreased significantly. In the last 30 years only 130 marriages taken place among the different Druze villages in the Golan Heights, only one marriage with a spouse from the village Hader at the side of the Syrian Mt. Hermon. In most cases of marriage were between Israeli Druze men og the Golan Heights with their Syrian female relatives. The social relationships with the Lebanon side of Mt. Hermon have also ceased to exist after the 1967 War. The relationships were partly renewed after the First Lebanon War (Yussef Abu Hassan, 2011 p. 45) [12].

\section{Research Methodology}

The research is qualitative, a "study case" focusing on the description of a phenomenon (Stake, 2005) [13]. Thus, an "holistic" approach exposes, examines and realizes the inner cultural world of the community members, from their point of view (Denzin \& Lincoln, 2000) [14].

According to this approach, behavioral origins are a result of definitions, beliefs, values and ideologies of "the people" (Pelto \& Pelto, 1978) [15]. Most of the field-research is based on built-in ethno-graphic' in-depth' interviews, these interviews are the primary source for information, allowing the Inter- viewee to tell her story freely, yet being focused on the research questions (Kapel-Green \& Miersky, 2013; Shkedi, 2011; Fontana \& Frey, 2005) [16] [17] [18]. The interviews were conducted among married women of Buqa'ata (The Israeli side of the Golan Heights) who were born in Syria, as an effort to examine their personal experiences (Spradley, 1979) [19]. The interviews' coordination was made by phone, and was carried out at the houses of the women for 50 minutes; each interviewee documented her story in writing.

As mentioned above, the "built-in interview" included 6 women the women were chosen with the helpful of the local citizens. The women were asked questions which were prepared in advance, by this following order (Hugh-Jones, 
2010) [20].

\subsection{Before Moving from Syria to Israel}

1) What was your parents' reaction towards your decision to marry a spouse from the Golan Heights?

2) What were your expectations of the new resident?

3) Were you mentally prepared to the transition?

4) Describe the separation from your family.

\subsection{The Arrival to the New Village/Home}

5) Describe your feelings when you first arrived your new village/home.

6) How did your husband's family accept you?

7) What was the major difficulty in the new village/home?

\subsection{The Present Time}

8) Tell me about your own family.

9) Describe your relationship with your husband's family today.

10) Do you think you have succeeded to adjust to the new place?

11) Do you think/believe you have made the right move by come living in the new place?

12) Do you support marriage of spouses from different countries?

13) What is your best advice for the new alleged bride that about to come from Syria to Israel?

After collecting the data (Table 1), they were examined carefully in accordance with the interview categories, each question apart. This process of separate analyzation is called the Etic Approach (Gabaton, 2001; Miles \& Hubermaan, 1994) [6] [21]. This approach focuses on gathering of topics and sub-context issues out of the answers (Glaser\& Strauss, 1967 : Miles \& Hubermaan, 1994) [22] [21]. Zabar (1995) [23] claims that this process is made without shortcuts, and thus, the researcher is looking for repeated prominent, important components, rephrasing categories, in order to sort, choose and analyze the categories, and place the content sections (Shkedi, 2010; Perakyla, 2005) [24] [25]. Shkedi (2003) [26] claims that in the process of collecting of data, we associate words and phrases into categories. These categories become meaningful only in relation to other categories.

\section{The Interviewees' Standpoint towards the Relocation from Syria to the Golan Heights in Israel}

All the interviewees said that the initial position of their family in Syria towards marrying a spouse from the Israeli Golan Heights, was an inconclusive refusal, as Umaima says "They rejected the idea from the beginning and they were angry at me for they had thought it was a poor decision. "The family members also had tried to convince the brides to alter their desion. Umaia ads "I was the most little and spoiled girl at home, and they have tried to convince me in any possible 
Table 1. Basic information about the study participants.

\begin{tabular}{ccccccc}
\hline Number & A fake name & Sex & Age & Place of birth & Years in Israel & Profession \\
\hline 1 & Nagwa & Female & 50 & Seida & 27 & Housewife \\
2 & Umaima & Female & 25 & Germana & 4 & Housewife \\
3 & Rim & Female & 47 & Germana & 26 & Housewife \\
4 & Asil & Female & 30 & Seida & 12 & Housewife \\
5 & Morgana & Female & 27 & Damascus & 6 & Housewife \\
6 & Gamila & Female & 34 & Jarmana & 9 & Housewife \\
\hline
\end{tabular}

way", she continues, "My mother didn't want me to leave and my brothers firmly refused, for I was their elder sister-kind of a mother for them, a sister and a friend.

Nagwa also describes the methods of persuasion, "They told me I was moving to a completely different life, everything will be new and odd, and I would not be able to adjust to life in the Golan Heights, would not be free to do whatever I desire". Eventually, one of the parents-the mother or father who had family in the Golan Heights, had supported her decision. As Morgana mentions, "eventually, my mother was pleased with the decision of marrying her nephew (her sister's son) and she was the one who had encouraged me to marry him, thus, it would strengthen the family ties with her far away sister, and would get the family close together". Gamila similarly says "My mother did not want me to get married and leave her, but my father had encouraged me because he wanted me to marry his nephew (his brother's son), even in the cost of leaving the family".

\subsection{Expectations Regarding Their Future Adjustment to the Vil- lage}

Most of the women's expectations were positive, optimistic and even hopeful, for some reasons. The first reason relates to natural-basic feeling of all brides, prior their marriage, as Rim explains "Every girl in my age dreams about a husband and waits for him a long time. I was expecting great life, great joy and great welcoming".

The second reason is related with the fact that most grooms are related by blood, most of them are their cousins, as Asil explains, "I knew my husband for we used talking on the phone, seen him in photographs and videos, for my husband is my cousin, this is why I had expected his family to accept me warmly and joyfully with kisses and hugs, for I should remind them of their dearest relatives that were left in Syria". The third reason is related to the family raising and marriage in Syria, and relocation to Israel afterwards, as Gamila explains "My husband remained in Syria for 15 years, during this period we had married in Syria and our son was born. I was the one to convince him to return to his homeland, family and his origins, thus, I was expecting a warm welcoming of his family and his village". The fourth reason is related to politics in the region, this 
is what Gamila states "when we were engaged, there were elections in Israel and we were expecting peace agreement with Syria, this is why I had agreed to move to the Golan Heights. Five months after we had moved, there were some incidents which had suspended the peace process, all my hopes that soon it would be peace and I would be able to see my parents have faded".

Only one of the 6 women-Umaia feared of the future "I was afraid that my husband's parents would not be happy to see me, I haven't any family in the village, however, I was sure that the community will be more open and welcoming, for they live in a more open and developed country".

\subsection{The Mental Preparation for the Relocation}

The analysis of the interviewees' statements indicates that half of them did not being prepared psychologically or had any other aid. In this respect, they describe the period as difficult, sad and painful for them. Each of the women had experienced the relocation differently. Morgana describes that the process was so fast that it had not left her time to prepare "I got engaged, dropped out of college for this reason, and had been told that the relocation would be by the end of the same week, It was very difficult for me, we (my family and I) were crying the entire week. It was not an easy situation because of all the sadness and crying, I don't remember anything, I was concerned merely in the idea of how would I leave my family? Gamila describes of being depressed- "I knew that the peace process will not continue and therefore got into a state of shock and depression, all my hopes to meet my family again in the future were vanished, I gave up, feeling I was in a funeral, breaking up from my friends and family without being able to see them in the future".

In contrast, the other interviewees who were mentally prepared to the relocation the element of time had a significant role. Rim explains this as follows "My family was separated for a long time, since I was little, one part lives in Syria while the other in Israel, still there was a connection between the two families, this is why I moved to the Golan Heights with my husband-to strengthen these relations, otherwise, I would had not consider leaving, or the distance". Umaia shares her bad experience, describing the ongoing crisis with her husband for many years "When I was a student we felt in love and he had asked to marry me and move to the Golan Heights, I refused for I didn't know anyone in the Golan. After three years, his parents asked him to return and we grew apart, but after a while we reunited, because of our love, and that how I started thinking about it and to convince my family". Nagwa is an exceptional, she was guided by her husband and went through own self convincing process "Of course It was difficult (at this point Nagwa started to cry and the interview stopped), I was a gifted student and left college in order to return with my husband to his homeland. Due to his description of the differences between the villages' customs, I was mentally well prepared. In addition, I convinced myself that it is only fair to leave my country, for he was alienated from his parents for 15 years, and the least that I could do is to make an effort and live far from my parents, in this way 
he could keep his house and property (land)".

\subsection{The Breakup from the Family}

The women (interviewees) describe the separation from the family in Syria in terms of a tragedy. Hence, during the week of the breakup, the families came to say goodbye to the bride, a very sad event which was accompanied with a lot of tears and sorrow. Nagwa describes her father's words crying (he died in the meantime), for she did not had the chance to break up from him. She remembered his words- "What would happen to me, if I get ill? Or die? Would you be able to come to my funeral?. All this time, people constantly came to say goodbye".

The toughest moment of the breakup was the separation on the border. At this point, Rim remembers "We all cried constantly until the end, keep reminded that we would not be able to meet again". Umaia describes "I gave a last gaze at everyone and said goodbye. It was extremely difficult to say goodbye to my mother, I saw my whole life passing as though I was in a movie, as if the border line ends it and I would never see my family again. I looked back and saw the line that had separated my beloved family from me; I raised my hand and waved them to goodbye". Gamila's pain is emphasized particularly when she talks about her brother "My whole family escorted me to the border, yet, what I remember the most is my brother filming and documenting my leaving from the moment I left home in Syria to the actual point of the breakup at the border, while I was walking towards Israel. I gave him a last glance but I forgot to say goodbye, I tried to go back to breakup with him properly, but I was not allowed. This was a very painful moment".

\subsection{The Arrival to the New Village-The Interviewees' Feelings}

Some of the women describe a sense of shock. As Morgana describes "I was in shock constantly, I thought all the time about my parents and how I left them. I felt I was entering into a long, dark maze in which its end is unknown, until I would get to know it better and find the light". The others felt strangeness. Asil explains "all faces seemed strange, because I didn't know anyone there. I felt helpless; even though everyone around me had tried to reach me, I was still crying and didn't want to see anybody". Gamila adds "I felt alien, I saw common faces but it wasn't compensating, for the fact that my parents were missing. The reality has changed and the new world was irritating and strange".

\subsection{The Acceptance by the Husband's Family}

All the interviewees stated emphatically they were welcomed warmly by the husband's family. The family's support was clear throughout the way to the village-during and after the wedding. Rim describes "During the time of the wedding and the parties, everyone made me feel I am part of the family. I was encouraged and it kept me avoid thinking or crying about the separation. They 
made me feel very important for being the first bribe to enter the border in a white dress, and also because of the fact that most people knew my parents from the period they had lived in Syria.

It should be noted that the social support granted mainly by women, and they play particularly active role in the process of adjustment. On the one hand, they were interested in the life in Syria, as Nagwa describes "All women and girls visited me and asked about my family, my life in the city of Al-Saweetha, codes of dressing, etc." Furthermore, they emphasized the importance of being united and the raising of a family, as Gamila describes "I was smiling despite my sadness". The hardest thing was to hide your emotions from others, though, they were happy that I brought back their son to his village. They always had told me that it would be OK and everything would pass, especially when I'll have my own little children and my own new family to compensate the break-up". Only Umaima has represented a criticizing position "Though the family did not know me and we do not share blood relations and I was warmly accepted, I didn't feel independent nor free in the house, unlike other family members, for we were living at my husband's parents' home".

\subsection{The Bribes' Initial Difficulties in the New Village}

The bride deals with quite few difficulties at time of arriving her new village. There are immediate technical and functional difficulties. The first difficulty is not having an ID card or any other official document which allows using medical care. Gamila describes “I couldn't get an ID card, thus was not allowed to admit a hospital or get medications. Only after 8 long years I got the ID card, by this time I had already paid a lot of money for medical treatments, I know there are lots of women in my condition". Asil added in the same context of health that "At the beginning when I did not have my ID card, I was refrained from getting pregnant in order to avoid paying thousands of Shekels".

Another basic difficulty is the new language- Hebrew. Rim explains "Everything on the Golan Heights is dependent on the Hebrew language and I had trouble with the language ". Umaima, who participated a Hebrew language course adds "The native language is Hebrew, without the language it is very difficult to communicate with government institutions like a hospital or work places. Although I have learned Hebrew, it was not enough, without continue speaking the language it might be forgotten, especially in my case that I was sitting at home and did not have anyone to practice the language".

Gamila refers the difficulty in finding work "Back in Syria I was a sportsteacher and earned good salary, I was hoping to find work in the new village, yet, school had rejected me despite my diploma. I didn't get any support nor fare chance". Morgana completes her and says "I'm sure it's not easy to find work in the village, especially when a lot of people have education. My husband is also a teacher and barely had found work. He works in the city of Be'er Sheva which is very far from our village". 
The second type of difficulty is on the socio-cultural scale. The first difficulty is the relocation from the big city in Syria into living in a small village. Nagwa explains "It was hard to adjust the difference between the developed city to the less developed, common village". Secondly, the criticism against the bribes, as Asil, Morgana and Nagwa describe, "everyone was criticizing my behavior and the way I am dressing... in Syria I used to feel special, for I was allowed to dress in this manner that was forbidden for most parts in the village... Every place has its own culture and it was very difficult for me to be restricted and criticized in the village".

Analysis of the interviewees' descriptions indicates that the greatest difficulty they had faced was the detachment from their family- parents, sisters and brothers who live in Syria. The difficulty is part of everyday life, as Umaima describes sadly "The hardest thing is to hear one of my neighbors saying she is going to visit her parents, I immediately get depressed. The holidays are the most difficult and painful, I'm far away from my parents, cannot see them and constantly thinking of them". The detachment from the parents gets extremely difficult at time of giving birth, as Nagwa describes "I felt helpless when I was giving birth my child and my mother wasn't with me. In each birth of my other children I was crying, remembering she is not with me. I found myself isolated, the only woman without her mother". Rim's story is particularly painful "all women who about to give birth are accompanied by their mothers. I still remember my first child's birth, I kept looking around for my mother. I went through a lot of difficulties, my daughter died at the age of 5 and it added to my pain, the absence of my parents. Even when they died I couldn't attend the funeral, nor see their bodies, it only added to my grief and pain".

\subsection{The Present Life}

The women understate their own-new family. They all feel very comfortable among their nuclear family of husband and children, yet the feeling is dual. On the one hand, they are happy in their family who they dearly love, on the other hand, they feel something is missing the family they had left in Syria. They all indicate it is non compensational e. Morgana testifies "now I feel comfortable, I have children to share with my daily life, especially with my daughters. Yet, although all this, I am still missing my parents, especially the absence of my mother. Nothing could compensate the fact that I can't see them". Nagwa says "I feel comfortable in the village, but in Syria it was even better among my parents and my family. I miss the closeness and warmth. I left in Syria also my dearest friend, and now, in an older age it is difficult to find another true friend. It is true that I feel relieved that my children are big and educated, but I still miss my family". Asil's description is an exceptional, she is very satisfied with the relocation and the change "In spite of all the difficulties I have faced I am happy with my life and my achievements, I live happily with my spouse, I have children and a warm family, and I feel comfortable in my new life, I don't regret it". 


\subsection{The Relationship with the Husband's Family in the Present Day}

All women indicate of close tied relationships with the husband's family. An analysis of Umaia ans Asil's description proves of natural strong relationships, "we are very close and there are no disputes between us, I spend most of my time with them, at home, because I live nearby and cannot be alone".

These kinds of relationships are enabled due to the children grandchildren as Gamila states “I can't spend a day without seeing or sit with my husband's family. Our relationship is built on love, respect and sharing of happiness, joy or sadness. I have three daughters who love their grandparents very much; yet, they always ask me about my parents, eager to meet them".

Morgana's answer is the most interesting. It emphasizes a closure of the issue of leaving he family in Syria. "Today I am a well -known woman, everyone respects me. Most of my husband's family has already died. My kids are well educated and have a family of their own. This is my compensation, to enable my children to acquire education. I even sent one of my children to study in Syria, in this way he gained meeting my parents. Today he is finishing fourth year in dentistry. These things encourage me; make me forget the sadness and enables me to welcome the future".

\subsection{Adjustment to the New Place}

The women's opinion of this subject were not similar, half, like Nagwa had a short decisive answer "Yes, I've adjusted to life", in contrast, Morgana argues that one cannot answer this parameter in terms of full adaptation, due to the social aspect "My adjustment wasn't perfect, for I don't have my former friends (from Syria) with me and I can't visit my parents as everyone else, only in Jordan. It is also difficult to travel without an ID card, carrying mainly a temporary document. Umaima and Gamila hold an entire different opinion of the lack of adjustment "Back in Syria I was a teacher with a regular salary while here I don't teach, I am on the margins and I got nothing...my personality fits in Syria only, only there I could fulfil my dreams, for the life there is better".

It is interesting that none of the women-interviewees relates to the aspect of culture.

\subsection{An Assessment of the Relocation in Terms of Life Progress}

Four of the five interviewees determined decisively that the relocation was fundamentally wrong. Again, most of them link this answer with the family disconnection which was created with their move to Israel, as Rim says "It's not the right move... why did I have to go through this? It is not easy to live in such pain and sadness, a girl needs her parents, especially at time of giving birth, although over time it all becomes better". Gamila adds "I can't live without my family. It kills me that I can't greet my mother on holidays, I am also concerned that if one my family would die, I won't be able to see him, and this only increases my pain". 
Morgana also believes that she had made a mistake, yet she relates it to lack of self-fulfillment "For years I didn't fulfill my dreams-I did not continued studying, I haven't worked at all, just sat at home and gave birth children. In Damascus there are more alternatives for female to learn and work freely, outside the village, here it is very difficult".

In contrast, Nagwa and Vasil believe the relocation was the right move, mainly for the sake of their children's future "I don't regret and I am convinced that I would be compensated by my children...they found home and are the legal heirs of their father and grandfather. If I had stayed with my husband

In Syria, they would be considered immigrants and had no legal heritage rights".

The position towards marriages of spouses from different countries

All the women-interviewees hold a positive, unified position towards marrying a spouse from a different country. However, they conditioned the approval in continuing seeing their family, as the following statement "I support this kind of marriage as long as there would be an open entrance to the country in both states, basing on peace agreement, thus, everyone would be able to see the family whenever they desire. It is especially good for brides who about to be married and leave Syria, the continuation of relation with the parents would makes the rest of the difficulties to be marginalized ".

\subsection{A Good Advice for a New Bride}

The women's advises to the new bribes are practical and include number of aspects. Nagwa suggests finishing school already in Syria, before coming to Israel. "At first, fulfil your dreams, finish school/college and then you would be able to work, to trust yourself and have confidence, thus, to be independent". Morgana offers to study about the life in Israel already in Syria, in order to ease her future adaptation "So she would understand situations in her new life, would learn the behavioral codes, what to expect, for everything differs Syria. It would greatly improve and facilitate her integration to the new life".

Asil suggests to listen to her "inner voice", to trust herself and the husband "Every bride needs to listen only to her inner voice, not to other people, not to worry, for everything would be fine, as long as she would try to understand the new society ... to be positive and have confidence in her husband, and most important, to have good harmony relationship with him".

Only Rim presents a different position. She opposes such kind of marriage as a result of own negative personal experience "I don't encourage anyone to marry and o be apart from her family, because my experience was hard. The political conditions are unknown, the experience is traumatic and cruel, I don't suggest anyone to experience this".

\section{Conclusion}

In light of this Table 2, we have come to the following conclusions:

A. adaptation of the bride does not occur in one particular period. It occurs 
Table 2. The adaptation of the Syrian bride.

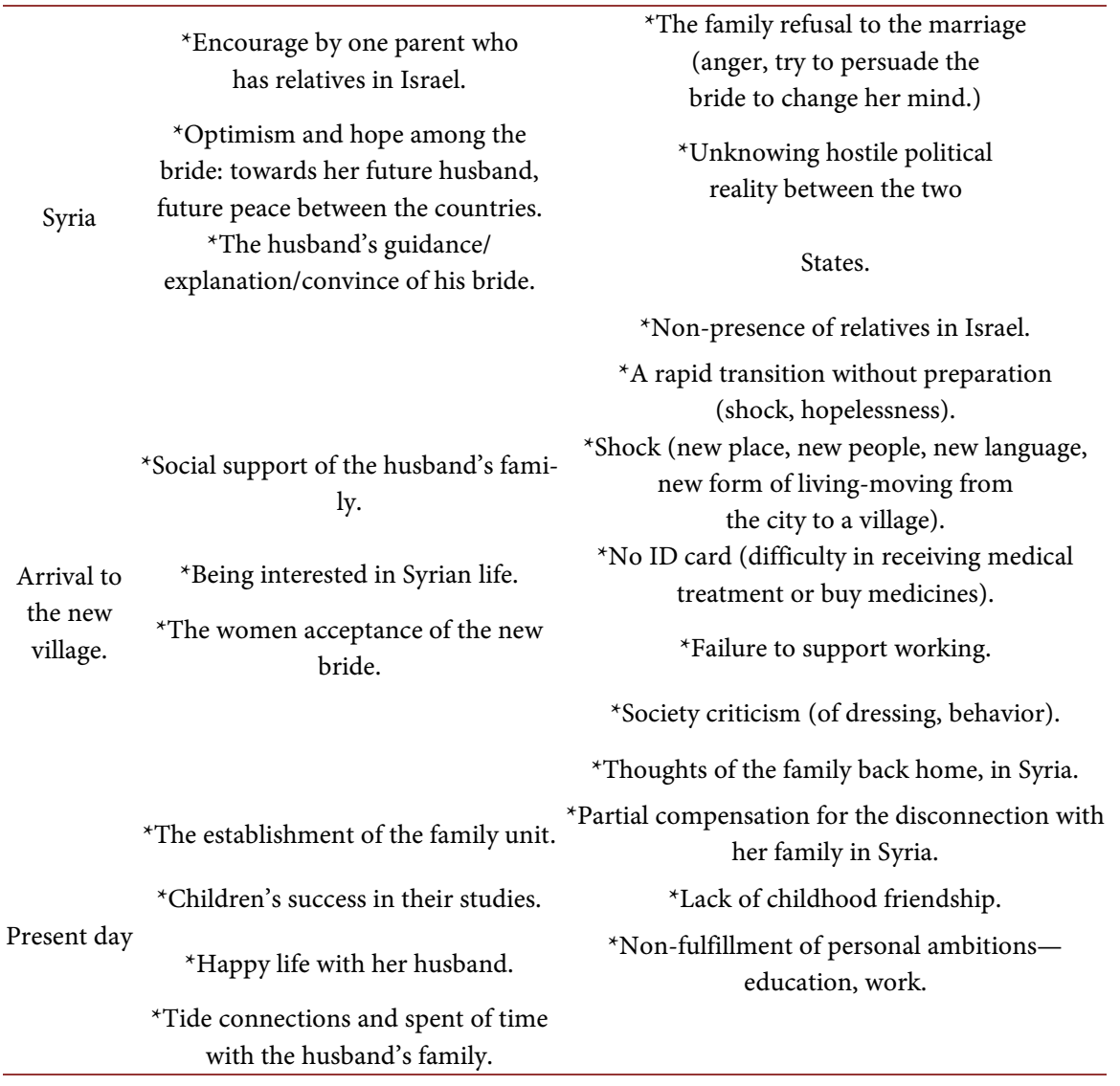

on a continuous time sequence (Syria-arrival to the village-present day).

B. The detaining factors of adaptation are greater than the supportive ones.

C. The social aspect plays an important role in adaptation, while cultural ones have minimum references, with the exception of criticizing the dressing and the behavior of the bride.

4. The families, both in Syria and in Israel, play a key role in the adaptation.

5. The adaptability of the bride does not end. That is to say, it is incomplete-the compensation of being apart and detached from her family and childhood friends, lack of self-fulfillment of personal ambition in the aspects of education and career.

\section{References}

[1] Faraj Falah, J. (2016) The Status of Druze Women in the Druze Religious Law in Comparison to Druze Women's Status in Society. International Journal of Multidisciplinary Research and Development, 3, 203-206.

[2] Fararj Falah, J. (2016) She Is a Widow: The Story of Six Druze Widows in Israel. Open Journal of Social Sciences, 4, 210-226. http://www.scirp.org/journal/jss

[3] Faraj Falah, J. (2005) The Druze Woman. Barkai Publications, Rishon Lezion.

[4] Falah Kasim, S. (1991) Nabaras Al-Mohadin. Elgalil Publication, Akko.

[5] Dana, N. (1999) The Druze in Israel. The Jerusalem Institute for Public Affairs and States. 
[6] Ben-Dor, G. (1996) The Druze Community: Religious, Historical \& Ideological Background.

Gabaton, D. (2001) A Theory Based on Field Experiment: The Meaning of Data Analysis Process and Qualitative Research Theory Design. In: Zabar, N., Ed., Traditions \& Trends in a Qualitative Research, Dvir, Tel Aviv, 195-228.

[7] Avivi, S. (2007) Tas Nehoshet-The Israeli Policy towards the Druze 1948-1967. Yad Ben-Zvi, Jerusalem.

[8] Shtandle, A. (1992) The Israeli Arabs between בין הפטיש לסדן Rock and a Hard Place. Akademon, Jerusalem.

[9] Al-Din (2000) Marital Engagements.

[10] Falah, S. (2000) The Druze in the Middle East: Historical Background. In: Falah, S., Ed., The Druze in the Middle East, The Ministry of Defense, Jerusalem, 19-45.

[11] Ram, D. (2010) The Issue of The Golan Heights. 3-4.

[12] Abu Hassan, Y. (2011) The Druze between Geography and Society. An inside Point View. Chaikin Cathedra of Geostrategic, Haifa University, Haifa.

[13] Denzin, N.K. and Lincoln, Y.S. (2000) Introduction: The Discipline and Practice of Qualitative Research. In: Denzin, N.K. and Lincoln, Y.S., Eds., Handbook of Qualitative Research, 2nd Edition, Sage Publication, London, 1-28.

[14] Pelto, P. and Pelto, G. (1978) Anthropological Research: The Structure of Inquiry. Cambridge University Press, Cambridge. https://doi.org/10.1017/CBO9780511607776

[15] Kapel-Green and Miresky, Y. (2013) In My Opinion, This Place Is a Naturereservation That I Really Need to Be Protectedt Mifneh School Staff Portrait. In: Alpert, B. and Shlasky, S., Eds., The Class \& School in Closer Inspection-Ethnographic Studies on Education, The Mofet Institute: Eilon Print, 108-140.

[16] Shkedi, A. (2011) The Meaning Behind the Words: Qualitative Research Methodologies. Ramot, Tel Aviv.

[17] Fontana, A. and Frey, J.H. (2005) The Interview: From Neutral Stance to Political Involvement. In: Denzin, N.K. and Lincoln, Y.S., Eds., The Sage Handbook of Qualitative Research, 3rd Edition, Sage Publication, London, 695-727.

[18] Spradley, J. (1979) The Ethnographic Interview. Rinehart, New York.

[19] Hugh-Jones, S. (2010) The Interview in Qualitative Research. In: Forrester, M.A., Ed., Doing Qualitative Research in Psychology, Sage Publications, London, 77-97.

[20] Miles, B. and Hubermaan, M. (1994) Qualitative Data Analysis: An Expanded Sourcebook. Sage Publication, Thousand Oaks.

[21] Glaser, B. and Strauss, L. (1967) The Discovery of Grounded Theory: Strategies for Qualitative Research. Aldine, Chicago.

[22] Zabar, N. (1995) The Qualitative Research in Teaching \& Learning. Modan.

[23] Shkedi, A. (2010) A Theory Based on Narratives: Constructing a Qualitative Research Theory. In: Kasen, L. and Cromer-Nevo, M., Eds., Qualitative Research Data Analysis, Ben Gurion University of the Negev Publications, Be'er Sheva, 463-461.

[24] Perakyla, A. (2005) Analyzing Talk and Test. In: Denzin, N.K. and Lincoln, Y.S., Eds., The Sage Handbook of Qualitative Research, 3rd Edition, Sage Publications, London, 869-886.

[25] Shkedi, A. (2003) Words Attempting to Touch-A Qualitative Research Theories \& Application. Ramot, Tel Aviv.

[26] Stake, R.E. (2005) Qualitative Case Studies. In: Denzin, N.K. and Lincoln, Y.S., Eds., 
The Sage Handbook of Qualitative Research, 3rd Edition, Sage Publications, London, 443-466.

Submit or recommend next manuscript to SCIRP and we will provide best service for you:

Accepting pre-submission inquiries through Email, Facebook, LinkedIn, Twitter, etc. A wide selection of journals (inclusive of 9 subjects, more than 200 journals)

Providing 24-hour high-quality service

User-friendly online submission system

Fair and swift peer-review system

Efficient typesetting and proofreading procedure

Display of the result of downloads and visits, as well as the number of cited articles Maximum dissemination of your research work

Submit your manuscript at: http://papersubmission.scirp.org/

Or contact jss@scirp.org 